\title{
A Student Review of Process Quality in Education: Teacher-Student Interactions and Language in Early Childhood Classrooms
}

\author{
Lisa D. Tafuro, Samatha Ferrara, and Kiley Cutichio
}

St. Joseph's College of New York, USA

\begin{abstract}
The social inequities across the fifty United States of America are indisputable. Widespread disparities in income and education fuel a persistent achievement gap. The gap, however, does not reflect children's lack of achievement. Instead, it reveals a lack of opportunity. Sadly, children across America have unequal access to quality education and, in particular, to quality early education (Takanishi, 2017). Programs vary in method, availability, and implementation, and, as a result, they distribute structures and processes of quality unevenly, primarily when serving lowincome children. One way to ensure quality in early learning across all communities is to improve teacher training. The literature suggests that training educators about teacher-student interaction patterns and how to embed educational dialogue in culturally sensitive ways can drive children's language and cognitive gains during the preschool years (Burchinal et al., 2008; Burchinal, 2018). Teachers' vocabulary and grammar impact students' long-term language performance. Teachers' language plays an integral role in children's ability to problem-solve, follow instructions, and deconstruct social contexts. Fundamental to children's learning is their socio-emotional competency and the ability to self-regulate. Teachers' language impacts children's ability to manage their behavior and engage with peers. Yet standards for teacher certification programs, curricula, and professional development do not exist. Current research out of Great Britain, Mexico, Canada, and the US highlights teachers' need to improve student interactions. Emotionally supportive and cognitively stimulating shared experiences with teachers may be one of the most powerful ways to effect change in early childhood classrooms, especially for diverse learners.
\end{abstract}

Keywords: early childhood education, student-teacher interaction, inequity, dialogue, quality process 


\section{Introduction}

Teachers' interactions and the language embedded in those interactions affect children's learning (Darling-Hammond \& Bransford, 2005; Girolametto, 2003; Yoshikawa, 2013). Studying the effectiveness of teacher training in language and dialogue can put us on the road to muchneeded education reform. The United States ranks behind many developed and some underdeveloped nations in offering young children high-quality early education. Too many children from low-income families arrive at kindergarten behind their more privileged peers because their programs lack process quality. According to current research, process quality, or the extent to which teachers engage in sensitive and responsive interactions with students, can predict language and cognitive gains (Guerrero-Rosada et al., 2021; Maeir, 2009; Pianta et al., 2014; Pianta, 2016). However, the best method for delivering and measuring process quality in preschool classrooms, especially those in low-income communities, is mostly unexplored (Maxwell et al., 2006). Administrators struggle to build programs that reliably produce positive child outcomes because they don't fully understand the mechanisms that best support teachers and children (Dickenson, 2011). "We must increase our understanding of the nature of teacher-child interactions in early education and how these interactions relate to outcomes" (Takanishi, 2007, p. 42). With a better understanding of classroom processes such as interaction and dialogue, we can help teachers create more effective teacher-learner interactions.

\section{Access to early childhood education}

Early childhood education supports children's long-term academic achievement (Burchinal, 2008). Unfairly, those living in low-income communities are susceptible to missing out on first experiences that prepare them for later learning. For many, early education is not a choice. 


\section{$2^{\text {nd }}$ International Conference on Modern Research in EDUCATION, TEACHING AND LEARNING}

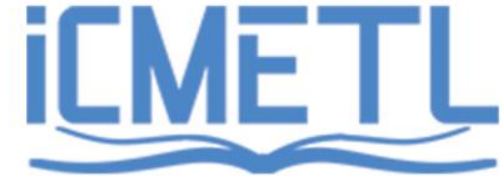

PARIS, FRANCE

20-22 NOVEMBER, 2020

Programs are either cost-prohibitive or do not exist. In states where preschool is not federally funded, tuition costs place these programs out of reach for many families. This lack of standard in preschool access across the fifty states leaves some children from culturally and economically diverse backgrounds with fewer experiences and learning opportunities. The result is that by the time these children reach their early elementary years, there is a significant disparity in academic skills relative to their privileged peers, coined the "achievement gap."

\subsection{Early childhood education quality across the 50 United States}

The cultural and economic divide in the U.S. is more than access to education; it is access to quality early education. Many different facets of the preschool experience define ECE quality. Pianta et al. (2016) and others identify four overarching quality measures in early childhood classrooms: Classroom structure (e.g., the number of hours children attend each day or teacher-student ratios); the physical space (e.g., classroom composition and playground features); direct student experiences as seen by the frequency and type of interactions students have with teachers; quality ratings and methods for improving student experiences.

Pianta et al. (2016) expressly point to teacher-student interactions as the most significant indicator of quality and children's academic success (Pianta et al., 2014; Pianta et al., 2016). Others frame the conversation in terms of quality of structure and process during the prekindergarten years (Burchinal, 2008). Studies in the U.S. and Portugal suggest that process quality, with roots in a social-ecological/interactionist model, has a direct positive relation to children's language learning in preschool (Abreu-Lima, 2013). Even with scientific support for high-quality ECE programs worldwide, many countries, including the U.S., continue to report substantial variation in both structural and process quality. For example, some children are enrolled for just a few short hours per week and have a very different experience from those enrolled in full-day programs. Other structural features, such as the teacher-student ratio, indirectly impact process quality. The 


\section{$2^{\text {nd }}$ International Conference on Modern Research in EDUCATION, TEACHING AND LEARNING}

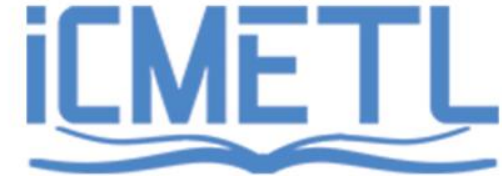

PARIS, FRANCE

20-22 NOVEMBER, 2020

frequency and type of interactions that children experience differ significantly due to how many hours they attend preschool.

\subsubsection{Classroom quality and teacher requirements}

There is a lack of standards or degree requirements in place for early childhood educators in the U.S. Not all ECE programs require teachers to have a Bachelor's or Master's degree. Some do not require a high school diploma. Current research highlights the benefit to children when teachers have an advanced degree. In light of this, education reform should address the varied standards and promote degree requirements while developing pre-professional curricular guidelines and requirements for courses and fieldwork that occur early and often, with adequate supervision and feedback. Survey research from new teachers indicated the more prolonged the student teaching experience, the more prepared teachers were to apply what they learned (Darling-Hammond et al., 2005).

Beyond general degree requirements, private and publicly funded preschools lack teacher standards. K-12 schools require teachers to have a bachelor's degree and specialization, with licensure and certification in place (Whitebook et al. 2009). Early childhood educators are not required to have these certifications, degrees, and fieldwork requirements. Traditionally in teacher preparation programs, foundational, pedagogical, and subject matter courses are prerequisite courses. The purpose of these requirements is to educate teachers about developmental theories, the philosophy and history of education, and provide exposure to teaching (Whitebook et al. 2009). We know teacher qualifications, such as higher education degrees and higher than average compensation, are features of early education that have significantly impacted children's learning (Yoshikawa, 2013). 


\section{$2^{\text {nd }}$ International Conference on Modern Research in EDUCATION, TEACHING AND LEARNING}

\section{ICMETL \\ PARIS, FRANCE \\ 20-22 NOVEMBER, 2020}

\section{Teacher preparation in dialogue and interaction}

Process quality includes children's classroom interactions with teachers and peers and directly relates to children's outcomes (Burchinal, 2018; Slot et al., 2017). Future research needs to identify a clear path to preparing teachers in this type of instructional support, especially for children in low-income communities. When teacher-learner interactions are sensitive and cognitively stimulating, they support children's sense of confidence, security, language growth, and academic achievement (Girolametto et al., 2003; Tafuro, 2012; Abreu-Lima, 2013).

Many teachers enter the early childhood education workforce underprepared without a degree in higher education or fieldwork experience (Whitebook et al., 2009). There is a striking difference in teacher qualifications in low-income, urban area schools with predominantly non-white students who find themselves in classrooms with the least skilled teachers (Lankford, Loeb, \& Wyckoff, 2002). Guidelines are needed to address teacher preparation in the processes that impact children's learning most significantly. As such, administrators and policymakers must focus on teachers' dialogic interactions to help build a competent workforce and ensure children's success. Teachers play an integral role in children's ability to problem-solve, follow instructions, and deconstruct social contexts. Fundamental to children's learning is their socio-emotional competency and the ability to self-regulate. Teachers' interactions and language impact their ability to manage behavior and engage with peers.

Despite this knowledge, minimal teacher requirements are the norm. Programs that require teachers to meet standards pull teachers from certification programs, curricula, and professional development programs that vary in terms of how they meet those standards. Overall, we know that most programs dedicate minimal attention to teachers' language in the classroom. Decades-long, multidisciplinary research supports the need for teacher-training programs to address quality 
teacher-student interactions. Embedding quality language in student-teacher interactions may well be one of the most powerful ways to effect change in the early childhood classroom and beyond.

\section{Conclusion}

The impact of this research is far-reaching. The large-scale project goals address issues of inequity in preschool classrooms worldwide. Bringing to light mechanisms that perpetuate the "education gap," such as a lack of teacher training in dialogic education (Hennessy, 2020) and language-based interactions, can positively impact children's lives. This review provides a body of evidence that argues for improved teacher preparation and the need to revise teacher training standards, especially in low-income and culturally diverse communities across the globe.

\section{Reference}

Abreu-Lima, I. M. P., Leal, T. B., Cadima, J., \& Gamelas, A. M. (2013). Predicting child outcomes from preschool quality in Portugal. European Journal of Psychology of Education, 28, 399-420

Burchinal, M. (2018). Child Development Perspectives. Measuring Early Care and Education Quality,12(1), 3-9. doi:10.1111/cdep.12260

Burchinal, M., Howes, C., Pianta, R., Bryant, D., Early, D., Clifford, R., \& Barbarin, O. (2008). Predicting child outcomes at the end of kindergarten from the quality of prekindergarten teacher-child interactions and instruction. Applied Developmental Science, 12(3), 140-153.

Darling-Hammond, L., \& Bransford, J. (2005). Preparing Teachers for a Changing World What Teachers Should Learn and Be Able to Do. San Francisco, CA: Jossey-Bass. 
Girolametto, L., Weitzman, E., \& Greenberg, J. (2003). Learning Language and Loving It ${ }^{\mathrm{TM}}$ - The Hanen Program ${ }^{\circledR}$ for Early Childhood Educators . Retrieved October 29, 2020, from http://www.hanen.org/Programs/For-Educators/Learning-Language-Loving-It.aspx

Guerrero-Rosada, P., Weiland, C., McCormick, M., Hsueh, J., Sachs, J., Snow, C., \& Maier, M. (2021). Null relations between CLASS scores and gains in children's language, math, and executive function skills: A replication and extension study. Early Childhood Research Quarterly, 54, 1-12.

Hennessy, S. (2020). CEDiR: Cambridge educational dialogue research. University of Cambridge Faculty of Education. Retrieved October 30, 2020, from http://www.educ.cam.ac.uk/research/programmes/analysingdialogue/

Lankford, H., Loeb, S. \& Wyckoff, J. (2002). Teacher sorting and the plight of urban schools: A descriptive analysis. Educational Evaluation and Policy Analysis, 24 (1).

Maier, A., \& Youngs, P. (2009). Teacher preparation programs and teacher labor markets: how social capital may help explain teachers' career choices Citation metadata. Journal of Teacher Education, 60(4).

Maxwell, k. L., Lim, C-I \& Early, D. M. (2006). Early childhood teacher preparation programs in the United States: National report. Chapel Hill, NC: The University of North Carolina, FPG Child Development Institute, 1-28

Pianta, R. C., Burchinal, M., Jamil, F. M., Sabol, T., Grimm, K., Hamre, B. K., \& Howes, C. (2014). Early Childhood Research Quarterly. A Cross-Lag Analysis of Longitudinal Associations Between Preschool Teachers' Instructional Support Identification Skills and Observed Behavior,29, 144-154. 
Pianta, R., Downer, J., \& Hamre, B. (2016). The Future of Children: Quality in Early

Education Classrooms: Definitions, Gaps, and Systems,26(2), 119-137.

Slot, P. L., Boom, J., Verhagen, J., \& Leseman, P. P. M. (2017). Measurement

properties of the CLASS Toddler in ECEC in The Netherlands. Journal of Applied

Developmental Psychology, 48, 79-91

Tafuro, L. (2011). Coordination and contingency in mothers' behaviors during interactions with their 14-month olds: Relation of infants' language development in a sample of first generation Mexican heritage families [Unpublished doctoral dissertation]. New York University.

Takanishi, R., \& Bogard, K. L. (2007). Child Development Perspectives. Effective Educational Programs for Young Children: What We Need to Know, 1(1), 40-45.

Takanishi, R. (2016). First things first!: Creating the new American primary school. Teachers College Press.

Whitebook, M, Gomby, D., Sakai, L., \& Kipnis, F. (2009). Effective teacher preparation in early care and education: Toward a comprehensive research agenda. Part II of Preparing teachers of young children: The current state of knowledge and a blueprint for the future. Berkeley, CA: Center for the Study of Child Care Employment, Institute for Research on Labor and Employment, University of California at Berkeley, 1-36

Yoshikawa, H., Weiland, C., Brooks-Gunn, J., Burchinal, M., Espinosa, L.M., Gormley, W.T., Ludwig, J.O., Magnuson, K.A., Phillips, D.A., \& Zaslow, M.J. (2013). Investing in Our Future: The Evidence Base on Preschool Education. New York: Foundation for Child Development and Washington, DC: Society for Research in Child Development. 